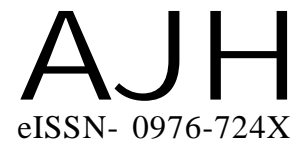

Received : 07.03.2017

Revised : 06.05.2017

Accepted : 20.05.2017
Members of the Research Forum

Associated Authors:

'Department of Horticulture, Faculty of Agriculture, Annamalai

University, ANNAMALAI NAGAR

(T.N.) INDIA

Email : anbumohankarthi2007@ rediffmail.com
Author for correspondence : K. MUTHUMANICKAM

Department of Horticulture, Faculty of Agriculture, Annamalai University, ANNAMALAI NAGAR (T.N.) INDIA Email : muthusai121@gmail.com
THEASIAN JOURNALOF HORTICULTURE

Volume 12 | Issue 1 | June, 2017 | 117-120

Visit us -www.researchjournal.co.in

\title{
Effect of combined application of inorganic and water soluble fertilizers on growth parameters of chilli hybrid (Capsicum annuum L.)
}

\section{K. MUTHUMANICKAM AND A. ANBURANI ${ }^{1}$}

ABSTRACT : An investigation was conducted to study the combined application of inorganic and water soluble fertilizers on growth parameters of chilli hybrid (Capsicum annuum L.) was carried out during 2015-2016 in the Pudhukuraipettai village at Virudhachalam Taluk in Cuddalore district. Foliar feeding of water soluble fertilizer NPK (19:19:19, 18:18:18, 13:40:13) at 0.5 per cent and 1 per cent with 5 sprays each starting from 30 DAT at 15 days interval, along with 100 and 75 per cent recommended dose of NPK $\left(120: 80: 80 \mathrm{~kg} \mathrm{ha}^{-1}\right)$ formed thirteen treatments in chilli hybrid cv. SIERRA. The experimental plots were laid out in Randomized Block Design and replicated thrice. The observations on various growth parameters were recorded and subjected to statistical analysis. The results obtained showed that 100\% RDF + WSF 1.0\% NPK @ 13:40:13 recorded the highest plant height, number of primary branches, stem girth, number of leaves per plant, leaf area, leaf area index and dry matter production.

KEY WORDS : Chilli, Water soluble fertilizers, Inorganic fertilizers, Growth parameters

HOW TO CITE THIS ARTICLE : Muthumanickam, K. and Anburani, A. (2017). Effect of combined application of inorganic and water soluble fertilizers on growth parameters of chilli hybrid (Capsicum annuum L.). Asian J. Hort., 12(1) : 117-120, DOI : 10.15740/HAS/TAJH/12.1/117-120. 